\title{
Intra-African Trade in the Context of Globalization: A Re-examination of the ECOWAS Protocol on Trade Liberalization
}

\author{
Fredrick O. Onyia \\ Department of Political Science, \\ University of Nigeria, \\ Nsukka, Nigeria
}

DOI: https://doi.org/10.36941/mjss-2020-0o64

\begin{abstract}
The Protocol on Trade Liberalization is one of the first five protocols that were originally annexed to the Treaty of ECOWAS. It was signed at Lome, Togo on November $5^{\text {th }} 1976$. To give further impetus to the Protocol, the Authority of Heads of States and Government at a summit held in Dakar, Senegal from July 2527, 1992 adopted some modifications of the Trade Liberalization Scheme. With the sweeping torrent of Globalization, ECOWAS member-states have found themselves in a dilemma. The dilemma arises from the fact that pursuing the goals of integration and at the same time embracing the gains of globalization creates a paradox. The study investigates whether ECOWAS Protocol on Trade Liberalization enhanced intraAfrican trade more than trade with third countries with the emergence of globalization. It is anchored on the neo-functionalist theory and made use of documentary method of data collection. The study contends that intra-African trade within ECOWAS has declined with globalization while trade with third countries has increased. The implication is that the stimulation and synergy of economies of member-states which Trade Liberalization is supposed to engender has been weakened. The study recommends a further revision of the provisions of the Trade Liberalization scheme by ECOWAS member states to align with the emerging realities of globalization. It further recommends the improvement of transportation infrastructure in the sub-region and mustering of political will by the leaders to implement their resolutions, among others.
\end{abstract}

Keywords: ECOWAS, Integration, Globalization, Protocol, Sub-region

\section{Introduction}

Stimulating and enhancing intra-African trade in West African sub-region is one of the major economic imperatives that gave fillip to the ECOWAS Protocol on Trade Liberalization.

The Protocol on Trade Liberalization is one of the first five protocols that were originally annexed to the Treaty of ECOWAS. It was essentially aimed at liberalizing trade within the community through the elimination of tariff and non-tariff barriers to free movement of goods within the sub-region. The Protocol was signed at Lome on $5^{\text {th }}$ November, 1976. Trade Liberalization on unprocessed agricultural products and handicraft became effective in May 1981, while experimental trade liberalization on selected industrial products originating from member states took off on January $1^{\text {st }}$, 1990.Having realized that the volume of trade with other countries far outweighs that among states in the sub-region, ECOWAS had to adopt trade liberalization as a veritable means for building more viable national economies (Onyia, 1993).

The advent of globalization from the early nineties has posed a dilemma to the realization of the 
original objectives of trade liberalization particularly with respect to intra-African trade. The dilemma arises from the fact that while trade liberalization within ECOWAS was originally targeted at member-states, globalization according to Oladoye(2006) seeks to remove all national barriers to the free movement of international capital and this process is accelerated and facilitated by the supersonic transformations taking place in information technology.

This paper interrogates the progress or lack of it that has been made by ECOWAS on intraAfrican trade since the advent of globalization. In the context of this study, intra-African trade refers to trade within the West African sub-region, but more specifically to trade between member states of ECOWAS, since not all countries in the West African sub-region belong to ECOWAS. The major question the paper seeks to interrogate is: Has ECOWAS Protocol on Trade Liberalization enhanced intra-regional trade within ECOWAS more than trade with non-member states of ECOWAS with the emergence of globalization. Arising from that, the argument in the paper is woven around the central hypothesis that with the advent of globalization, intra-regional trade within ECOWAS has declined while trade with non-member states has grown.

This paper is divided into six sections. Section one is this introductory part which delineates the focus of the study. In section two, we state the theoretical framework that guides the study. Section three is an overview of ECOWAS Protocol on Trade Liberalization as well as the concept of globalization. Section four addresses the nature of intra-regional trade in a regime of globalization. This is followed closely in section five which contains the findings and policy implications. The paper concludes in Section six with recommendations.

\section{Theoretical Framework}

Our analysis in this study will be anchored on the Neo-functionalist theory of integration - a theory whose major exponent is Ernst B. Hass. The kernel of Neo-Functionalism is its stress on the individual motives and interests of elite groups involved in the process of integration. Related to that point is its emphasis on the role of self interest in shaping the perception of integration. It places premium on the motivation of the actors and intended and unintended consequences of their individual pursuit of self-interest.

In very simple terms, the theory states that the existence of institutions which perform common or joint functions tends to enhance understanding and cooperation among members. But the performance of these functions has to be at the cost of some deprivation. This therefore demands some sacrifice from members. As common functions become fruitful, more are added. Nevertheless, the addition of these functions is not automatic. Since carrying out of joint functions brings about some deprivations, there has to be the political will to ensure that the problems it creates are counteracted. It follows, that new functions will only be added if the members benefit from the previous functions performed.

The proponents of the theory further argue that if the members do not derive any benefit, they will be reluctant to take on new functions. In other words, the transfer and generalization of integrative lessons learned and habits formed in one context of functional collaboration to another will only occur if actors on the basis of interest-inspired perception desire to adapt integrative lessons learned in one context to a new situation. What stimulates this desire is the extent to which they have gained from previous experiments. In an integrative scheme, participants in an institution performing joint functions will only add new ones if the previous functions carried out are beneficial to them.

As applied to this study, it is noteworthy that ECOWAS as a sub-regional integrative arrangement was contrived to coordinate the performance of certain functions. For these functions to be carried out, member states have to make some sacrifice. Arising from this, the success achieved in performing previous functions determines the addition of new ones. Evidence shows however that individually, member states suffer more deprivation, though collectively the group gains. As an illustration, the trade liberalization scheme which tends to eliminate custom duties and charges of 
equivalent effect leads to revenue loss by member states. Consequently, when decisions are taken by the highest organs of ECOWAS, member states feel reluctant to implement them. Put differently, since member states do not benefit from the performance of joint functions, they develop a lukewarm attitude when called upon to add new ones.

Using this analytical framework, it becomes a bit more comprehensible why intra-community trade within the sub-region has remained relatively low compared to external trade with the rest of the world.

\section{ECOWAS Protocol on Trade Liberalization}

It is the Protocol Relating to The Definition of The Concept of Products Originating from Member States of ECOWAS that is generally referred to as the Protocol on Trade Liberalization. It was signed at Lome, Togo on $5^{\text {th }}$ November 1976. The Protocol was designed to be accomplished in stages. First, elimination of tariff barriers on unprocessed agricultural products and handicrafts began in 1981 and was expected to be completed in 1989. To qualify for the scheme, the product must be accompanied by certificate of origin attesting that the product could be approved to benefit from the scheme if it is from an enterprise of which indigenous equity participation is at least $40 \%$ with $60 \%$ of local raw materials input and at least 35\% local value added.

Next, is elimination of non-tariff barriers on unprocessed products? This also began in 1981 and was expected to be completed in 1985 . Further, there is the abolition of tariff on a list of priority nonfactory products on the basis of $25 \%$ annual reduction. This should be done in four years, $1983-1987$. Moreover, there is the abolition of tariff on a list of non-priority, non-factory products. This should be done on the basis of $16.66 \%$ annual reduction in six years, 1983-1989.

The Protocol listed a wide range of products which shall be accepted as originating in MemberStates for the purposes of trade liberalization. These are essentially agricultural products, minerals, livestock, fishery and manufactured products as well as scraps and waste resulting from manufacturing operation within the member-states. With respect to manufactured products, Article 2(c) of the Protocol stipulates that "if the goods have been produced from material of a foreign or undetermined origin and having received in the process of production a value added of at least $35 \%$ of the freight on board (f.o.b) price of the finished product, they shall qualify to be admitted under the Trade Liberalization scheme".

Article 3(1) further stipulates that evidence of community origin shall further be substantiated by a certificate of origin issued by the competent authority designated for that purpose by the exporting member state where the goods have been produced and countersigned by the customs department of that member-state. The certificate should indicate therein the percentage and origin of the materials used and or the percentage of value-added as the case may be.

A fundamental point worth noting is that a Certificate of origin does not automatically create a free passage for goods to the importing country. This is because the importing country reserves the right to make further verifications of the claims made in the certificate of origin in case of doubt. This is succinctly stated in Article 3(2). Indeed, determining the origin of goods involves much more than mere declaration in a certificate of origin. It is not just the point of departure of a commodity that confers community origin, for as contained in Article 4, there are processes and operations which shall be considered as insufficient to support a claim that goods originate from a member-state. They are as follows:

- Packaging, bottling, placing in flasks, bags, cases, boxes, fixing on cards or boards and all other simple packaging operations.

- Operations to ensure that preservation of merchandise in good condition during transportation and storage such as ventilation, spreading out, drying, freezing, placing in brine, sulphur dioxide or other aqueous solutions, removal of damaged parts and similar operations.

- Changes of packaging and breaking up or assembly of consignments. 
- Simple assembly of parts of a product to constitute a complete product.

- Making or labeling for distinguishing products or their packages.

- Simple operations consisting of removal of dust, sifting or screening, sorting, classifying, matching, including the marking up of sets of goods, washing, painting or cutting up.

Of significance is that mixing of products does not confer origin. Arising from that, origin shall not be conferred on any product resulting from the mixing together of goods which would qualify as originating in the member states with goods which would not so qualify, if the characteristics of the product as a whole are not essentially different from characteristics of the goods which have been mixed. This is stated in Article 8(1).

Another important element given attention by the Protocol has to do with determining the value of materials imported from a third country but used in the process of production in a member country. This is treated in Article 6(a) and (b) which provides that the value of such materials should be their Cost, Insurance and Freight (C.I.F)value accepted by the customs authorities on clearance for home use, or on temporary admission, at the time of last importation into the member state where they were used in a process of production less the amount of transport costs incurred in transit through other member states. However, if the value of any materials imported from outside the member states cannot be determined in accordance with C.I.F, their value shall be the earliest ascertainable price paid for them in the member state where they were used in a process of production.

The Protocol envisaged that cases might arise where it will be difficult to separate materials of similar character but different origin used in the production of goods. Consequently Article $7(1)$ provides that "such segregation may be replaced by an appropriate accounting system which ensures that no more goods are deemed to originate in the member-states than would have been the case if the producer has been able physically to segregate the materials". It shall conform to such conditions as may be agreed upon by the council in order to ensure that adequate control measures will be applied.

To ensure that the provisions of the Protocol are adhered to, member-states undertake to introduce legislation, making such provision as may be necessary for penalties arising from false claims that goods should be accepted as originating from the member-states. In case of such an untrue claim, that matter shall immediately be brought to the attention of the exporting memberstate from which the claim is made so that action can be taken (Art. 13(1)(2). The responsibility for making regulations concerning proof and the verification of proof of goods originating from memberstates is entrusted on the Customs Cooperation Council.

At the $15^{\text {th }}$ summit of the Authority of Heads of State and Governments of ECOWAS held at Dakar, Senegal from July $25^{\text {th }}-27^{\text {th }} 1992$, the leaders adopted some modifications to the Trade Liberalization Scheme. First, is the adoption of $25 \%$ for indigenous participation in the equity capital of enterprises producing industrial goods for intra community trade? Secondly, the scheme is also to be simplified by abolishing the categorization of industrial products on priority and non-priority basis.

At this juncture, it is pertinent to state that two principal objectives which accompany any economic integration are the elimination of tariff and non-tariff barriers on goods traded among member countries as well as the imposition of a common external tariff against goods from third countries. A cursory look at the provisions of the Protocol on Trade Liberalization suggests seemingly stiff regulations with respect to defining what constitute goods of community origin. Nevertheless, they are designed to ensure that goods from third countries do not enjoy these preferential trade arrangements. If the guidelines are not strictly enforced, the tendency will be for goods from third countries to be treated as community goods. When this happens, the gains which are supposed to be derived from the scheme will be cancelled out.

The Trade Liberalization scheme seems to be predicated on the assumption that member states will willingly sacrifice their short term material interests for the greater interest of the sub-region as a whole. Although it is generally agreed that Trade Liberalization within a grouping maximizes 
economic efficiency from the groups point of view by comparison to a non-trade situation, but it should be realized that some countries or groups within the community will be hurt by the dismantling of trade barriers despite the fact that the gain is larger for the members of the group as a whole.

Practical experience with economic integration in various parts of the developing world has shown that the application of free-trade area and customs union rules raises a very serious problem which may hamper the integration scheme. This problem arises from the unequal level of development of the countries or regions forming an integrated area. To put it simply, one can say that in such an area, the less industrialized partner tends to subsidize the more industrialized by buying its manufactured products above world market prices, whereas in general, it has to sell its raw materials and food stuffs at world market prices outside and even inside the integrated area.

The Trade Liberalization scheme seems to be well crafted to provide a level playing field for member-states. This could be seen in the compensation it provides for losses sustained by any member state due to the abolition of tariffs. But bearing in mind that member states would be more inclined to look for quick rewards rather than take a long term view of the benefits of cooperation, the tendency to cheat by falsifying figures on intra-community transactions in order to qualify for compensation would be more pronounced.

In relation to the above point, although issues of false claims can be brought to the notice of the exporting member-state, so that action can be taken, this is not strong enough to deter member states from cheating. What is more, a member state is under no obligation to institute or continue court proceedings against a defaulting exporter without the permission of the importing member state.

Another remarkable point about the Protocol is that there is a disparity in the elimination of tariff and non-tariff barriers. Article 1 of the Decision of the Authority of Heads of State and Government relating to Trade Liberalization on industrial products which was signed at Lome on $28^{\text {th }}$ May 1980, states that, "Trade Liberalization on industrial products and elimination of tariff barriers shall be governed by the following schedule:

\subsection{Products of Community Enterprises}

- Such products shall be liberalized immediately they are produced and they shall have free access to the community market duty free.

- Priority industrial products to enjoy accelerated liberalization.

On the contrary, Article 11 which is on the Elimination of non-tariff barriers states, "for the purposes of eliminating non-tariff barriers, the following scheme shall apply:

- All member states shall be treated on the same level.

- The method of liberalization shall be left to the discretion of member states.

- Liberalization shall be undertaken at a faster rate than tariff barriers and shall be eliminated over a period of four years commencing from $28^{\text {th }}$ May, 1981.

While paragraph three states that liberalization shall be undertaken at a faster rate than tariff barriers, the same Article under paragraph two leaves the method of liberalization to the discretion of member states. Knowing fully well that member states are bound to apply different methods of liberalization, based on suitability to their domestic interests, efforts to accelerate liberalization will come to naught.

The Trade Liberalization Protocol is sufficiently flexible that it allows members a wide range of choice and as observed by Onyia (1993) its provisions are recommendatory rather than mandatory. Bearing in mind that ECOWAS has no mechanism for enforcing its decisions, there is nothing that compels member states to comply with the provisions of the protocol. Even if there were coercive institutions for enforcing decisions, they might still be rendered ineffective since any action contemplated against a member state will bring in the question of state sovereignty. The whole issue of integration is a matter of Will rather than Power (Onyia, 1993, p.80). 


\section{The Paradox of Globalization}

The concept of globalization has different interpretations, but in the academia, there is some degree of consensus among scholars on what the term globalization means. Though it has various components, the core is the economic component. Economic globalization implies economic interchange between various nations of the world, which is capable of generating growth and general development, based on the opening of different economies and facilitation of competition in and around nations (World Bank, 1996). Globalization refers to the growing integration of the global economy which is being brought about by the incessant flows of goods and services, capital, technology and information across national borders. It deals with the increasing breakdown of trade barriers and increased integration of world market (Oladoye, 2006; Fafowora, 1998). Globalization and interdependence elicit four basic essentials comprising trade and transactions; capital and investments; migration and movement of people; dissemination of knowledge and technology (IMF, cited in Okolie \& Eke, 2016).

In the words of Sodaro (2008, p.16) "globalization refers to the growing interconnectedness of governments, non-state actors, and populations throughout the world through a variety of political, economic, technological, cultural, environmental and other interactions". He goes further to state that it is a multifaceted phenomenon and its components interact in all sorts of ways, yet economic factors stand out as its principal motor force, while technology provides its thrust. In his words "economics is the engine of globalization, technology its fuel". The establishment of World Trade Organization (WTO) in 1995 was designed to facilitate these global economic links, he further argues.

Moravcsik (2008, p.234) opines that the universal condition of world politics is globalization. States, he opines are, and have always been embedded in a domestic and transnational society that creates incentives for its members to engage in economic, social and cultural interactions that transcend borders. This point helps to illuminate the concept of Regional Economic Groupings as exemplified in ECOWAS.

It is important to add here that globalization is a political neologism which became a dominant motif in the discourse of international economic relations from the early nineties, following the end of the cold war. It could be likened to Perestroika (restructuring) and Glasnost (Openness) which President Mikhail Gorbachev introduced in 1989 in Soviet Union to free up the soviet economy from state control and open it to the world. In this connection, globalization represents the restructuring and opening up of the world economy through a variety of international linkages.

Conceptually, globalization and trade liberalization are not diametrically opposed. Both emphasize removal of restrictions to free movement of goods, services, capital and labor. However, in the context of ECOWAS, trade liberalization as originally conceived was intended to remove these barriers in order to first and foremost enhance trade within the West African sub-region. It was not meant to open their markets without restraint to the outside world. The idea among member states of ECOWAS was to first "put their house in order" before launching into the global arena, since in doing so; they will be putting their best feet forward.

However, globalization has extended the frontiers of trade liberalization beyond the confines of regional economic groupings like ECOWAS. Rather than acting regionally, it emphasizes acting globally. This has drawn ECOWAS member states into a global competition, they were ill prepared for, arising from the low level of development of productive forces compared to American, European and Asian economies. With this scenario, there seems to be a mismatch between the original intent of ECOWAS trade liberalization and the more holistic demands of globalization. This is what is construed in this section as the paradox of globalization.

\section{Intra-African Trade within ECOWAS}

One of the major goals ECOWAS trade liberalization scheme was meant to achieve was to boost trade among member states. This was envisaged as a vehicle for actualizing the dream of making the sub- 
region a formidable economic bloc. In the course of the journey, however, several road blocks have been encountered which derails the attainment of these objectives. Some of these are fortuitous, while others are contrived.

As an illustration, countries in the sub-region have different natural resources endowments and technological capacity. This finds expression in the types of goods produced and traded in the community; a situation that has prompted Ereke et al (2016) to insinuate that goods produced and traded by member states do not complement one another. As a result, member states use all kinds of barriers to prevent their neighbors from having access to markets in their territories. Fayomi \& Adeola (2015) expressed a different sentiment with respect to trade in the sub-region. For them, the absence of a convertible currency has not encouraged intra-community trade. Rather, the existence of competing currencies breeds frustration.

After more than forty-five years of existence, exports that originate from ECOWAS countries still comprise primary commodities with little value addition. What is more demeaning is that the percentage of intra community exports is abysmally low compared to exports to non-African countries

Between 2000 and 2009, intra community exports within ECOWAS were $8.8 \%$. In 2009 intra community exports within ECOWAS was $9.9 \%$. However, a few countries dominate exports. In ECOWAS, $77 \%$ of exports come from two countries - Nigeria $45 \%$ and Cote d'Ivoire $32 \%$. (IMF DOTS, Feb. 2011, as cited in Hartzenberg, 2011, p.10).

Intra-regional imports in ECOWAS have also shown a growing trend. It averaged $9.6 \%$ from 2000 - 2009. In 2009, it dropped to $8.1 \%$. A significant portion of imports were destined to a few countries. $58 \%$ of imports were destined for three countries namely Cote d'Ivoire (23\%), Ghana (23\%) and Nigeria (12\%). (IMF DOTS, Feb.2011 as cited in Hartzenberg, 2011, p. 12).

Table 1: Share of Exports from Africa's Regional Economic Communities to Partner Regions in 2012 and 2015

\begin{tabular}{|c|c|c|c|c|c|c|}
\hline \multirow[b]{2}{*}{ Regional Economic Community } & \multicolumn{2}{|c|}{$\begin{array}{l}\text { REC Member } \\
\text { Countries }\end{array}$} & \multicolumn{2}{|c|}{$\begin{array}{l}\text { Non-REC Member } \\
\text { African Country }\end{array}$} & \multicolumn{2}{|c|}{$\begin{array}{l}\text { Non-African } \\
\text { Country }\end{array}$} \\
\hline & 2012 & 2015 & 2012 & 2015 & 2012 & 2015 \\
\hline ECOWAS & 7.6 & 12.1 & 5.0 & 6.3 & 87.4 & 81.6 \\
\hline South African Development Community (SADC) & 17.3 & 19.5 & 2.3 & 2.7 & 80.4 & 77.8 \\
\hline East African Community & 19.1 & 18.1 & 13.9 & 15.2 & 66.4 & 66.6 \\
\hline Economic Community of Central African States & 0.8 & 1.5 & 4.1 & 4.9 & 95.1 & 93.6 \\
\hline Arab Maghreb Union & 2.1 & 3.4 & 1.3 & 2.7 & 96.6 & 93.9 \\
\hline
\end{tabular}

Source: Adapted from IMF, data http://.imf.org as cited in AFDB/OECD/UNDP Africa Economic Outlook 2017, p.88

The figures above show that in terms of percentage of exports traded within the Regional Economic Communities, ECOWAS ranks below South African Development Community (SADC) by $15.1 \%$ and East African Community by $16.5 \%$ for the two years under review. SADC as presently constituted was set up on August $17^{\text {th }} 1992$, seventeen years after ECOWAS, though it is an off shoot of South African Development Coordination Conference (SADCC). East African Community on the other hand was set up in 1967.

For exports destined to non-African countries, that of ECOWAS is higher than SADC by $10.8 \%$ and East African Community by as much as $36 \%$ for the two years under review. This is a sad commentary on intra-African trade which ECOWAS trade liberalization is meant to champion. Most of the primary exports that originate from ECOWAS countries, undergo little processing before they are re-exported. This is true for cocoa beans from Cote d' Ivoire and crude oil from Nigeria (AFDB,OECD/UNDP Africa Economic Outlook 2017, p.83). Table 2 below illuminates this point. 
Table 2: Evolution of Value-Added of total industry and of manufacturing in selected ECOWAS Countries $1990-2015$

\begin{tabular}{|c|c|c|c|c|c|c|c|c|c|}
\hline \multicolumn{2}{|r|}{1990} & \multicolumn{2}{|r|}{2000} & \multicolumn{2}{|r|}{2005} & \multicolumn{2}{|r|}{2010} & \multicolumn{2}{|r|}{$2015(a)$} \\
\hline Industry: & $\begin{array}{c}\text { of which } \\
\text { manufacturing }\end{array}$ & Industry: & $\begin{array}{c}\text { of which } \\
\text { manufacturing }\end{array}$ & Industry: & $\begin{array}{c}\text { of which } \\
\text { manufacturing }\end{array}$ & Industry: & $\begin{array}{c}\text { of which } \\
\text { manufacturing }\end{array}$ & Industry: & $\begin{array}{c}\text { of which } \\
\text { manufacturing }\end{array}$ \\
\hline \multicolumn{10}{|c|}{ Cote de Ivoire } \\
\hline 23.1 & 14.3 & 23.4 & 17.6 & 25.5 & 16.1 & 24.7 & 15.0 & 28.9 & 16.6 \\
\hline \multicolumn{10}{|c|}{ Burkina Faso } \\
\hline 21.2 & 14.4 & 25.1 & 13.2 & 18.0 & 11.7 & 20.5 & 7.5 & 20.2 & 6.5 \\
\hline \multicolumn{10}{|l|}{ Ghana } \\
\hline 22.5 & 9.6 & 28.4 & 10.1 & $27 \cdot 5$ & $9 \cdot 5$ & 19.8 & 7.0 & 26.3 & 5.0 \\
\hline \multicolumn{10}{|l|}{ Nigeria } \\
\hline $45 \cdot 3$ & 5.5 & 52.2 & 3.7 & 43.5 & 2.8 & 25.3 & 6.6 & 30.4 & 9.5 \\
\hline \multicolumn{10}{|l|}{ Senegal } \\
\hline 22.2 & 15.3 & 23.2 & 14.7 & 23.7 & 15.1 & 23.4 & 13.7 & 33.4 & 13.2 \\
\hline
\end{tabular}

Source: AFDB, OECD/UNDP Africa Economic Outlook 2017, p.177

Another issue that impacts negatively on intra-African trade within ECOWAS is geography. Of the fifteen countries in Africa that are landlocked, three are in West Africa and belong to ECOWAS. These are Burkina Faso, Mali and Niger. Being landlocked, denies a country the opportunity of accessing natural resources that abound in the sea. In the same vein, landlocked countries cannot utilize the sea for trading and transportation.

Thus, in ECOWAS sub-region where trade is liberalized, landlocked countries are unable to take full advantage of the gains of trade liberalization as exports and imports are conducted majorly by road. Conducting international trade via this route comes with relatively high costs and delays. Collier, (2007, pp. 56-7) underscored the challenges that landlocked countries face when he stated: "being landlocked in a poor geographic neighborhood is one of the four major development traps by which a country can be held back in general. Landlocked countries are limited in their trading activity with the rest of the world. If you are coastal, you serve the world; if you are landlocked, you serve your neighbors".

However, there is a sense in which being landlocked could confer an economic advantage to a country. This view was expressed by Moseley et. al. (2010) who argued that being landlocked may actually be a blessing as it creates a natural "tariff barrier" which protects the country from cheap imports. All things considered, the fact that three out of fifteen countries in ECOWAS are landlocked, should not have a disproportionate impact on intra-African trade if the other twelve members are committed in driving the process.

ECOWAS is also weakened in advancing the goals of trade liberalization as a result of the position its members occupy in the World Human Development Index ranking. Of the 42 countries classified as least developed by the United Nations Centre for Trade and Development (UNCTAD), using the HDI composite statistics of education, life expectancy and per capita income, 11 are members of ECOWAS. These are Benin, Burkina Faso, Gambia, Guinea, Guinea-Bissau, Liberia, Mali, Niger, Senegal, Sierra-Leone and Togo. (Retrieved on 6/2/18 from http://unctad.org/en/pages/ALDC/Least\%Developed\%20 countries/UN-list-of-least-Developed countries). Only four ECOWAS countries namely, Cote de'Ivoire, Nigeria, Ghana and Cape Verde were not so classified.

The four basic essentials which globalization and interdependence elicit as identified by IMF are trade and transactions; capital and investments; migration and movement of people; dissemination of knowledge and technology. These are the very essentials that have rendered intra-African trade within ECOWAS nugatory. What with the massive inflow of goods, capital and technology from China and India. The economic gains which ECOWAS countries derive from such intercourse acts as a centrifugal force that pulls them away from the objectives of the Trade Liberalization scheme.Thus 
globalization seems to be working at cross purposes with the goals of ECOWAS Trade Liberalization.

Atakpa (2015, p.142) put it this way:

Globalization has spelt disappointment for the developing countries whose position in the international regime has been gravely marginalized. Thus while restrictions have been lifted on the freedom of capital and skilled labor to move to areas of high returns, the restrictions on the mobility of unskilled labor remain. Moreover, as developing countries have increased their capacity to produce and export manufactures, developed countries have become active in promoting tariff peaks and escalations

Oladoye (2006, p.4) further contends that:

The exclusion of countries and people from the benefits of globalization is further compounded by the emerging rules of the game for international economic transactions which remains asymmetrical in terms of construct and inequitable in terms of outcome.

\section{Findings and Policy Implications}

ECOWAS is strong in resolutions and weak in implementation. In 2006, in what seemed to be a great leap forward, it revised its original Treaty and restructured its institutions. The Executive Secretariat became the Commission; the Fund for Cooperation, Compensation and Development became the ECOWAS Bank for Investment and Development while the Community Court of Justice and the Parliament were strengthened. These changes were ostensibly aimed at making the institutions more relevant and to adapt to the challenging demands of globalization. In the same vein, the body adopted a common external tariff in January 2015. This was to obviate the loss in revenue that arises from having a competitive external tariff regime among member countries. It was also meant to address the challenges arising from meeting the requirements of rules of origin for the purposes of trade liberalization.

The institutional reforms, notwithstanding, the journey in the road towards achieving the original objectives of Trade Liberalization is still far from being reached. The programs of the French speaking members of ECOWAS have always worked at cross purposes with the English speaking countries. Of the fifteen member states of ECOWAS, eight states, namely Benin, Burkina Faso, Cote d'Ivoire, Guinea-Bissau, Mali, Niger, Senegal and Togo belong to another regional economic grouping, called, West African Economic and Monetary Union, otherwise known as UEMOA (L'Union Economique et Mone'taire Quest African) The attitude of the member states of UEMOA towards the integration scheme are usually influenced and dictated by France, their former colonial masters. UEMOA has a monetary and financial arrangement that is based on a common currency, the CFA franc and a Central Bank (Camara, 2001).

Sylla (2017) further observes that CFA franc is the monetary accord between African nations and France, and it is an accord with four main pillars. First is a fixed rate of exchange with the euro (and previously the French franc) set at 1 euro $=655.957 \mathrm{cfa}$ francs? Second, a French guarantee of the unlimited convertibility of cfa francs into euros. Thirdly, a centralization of foreign exchange reserves and finally, the principle of free capital transfer within the franc zone. This robust financial arrangement makes it easier for UEMOA member states to transact more trade among themselves and difficult to trade with the rest of ECOWAS. At the same time, it links their trade externally with France.

However, in December 22, 2019, in what seemed like a bold move, the eight West African countries in the CFA monetary arrangement renamed their currency ECO and stated that going forward; it will cut off CFA francs links to former colonial powers France. The change which was announced by President Alhassan Quattara of Cote'd'Ivoire were three pronged. First, is the change of the currency name from CFA francs to ECO? Second is a discontinuation of holding 50 per cent of the reserves in French Treasury. Third is the withdrawal of French governance in any aspect related to the currency? Even with these changes, the fact that eight countries out of fifteen ECOWAS 
countries have a common currency while the other seven do not have, still makes trading within the French speaking bloc easier than the rest of the sub-region. The other seven countries have their own currencies, none of which is freely convertible.

In ECOWAS, actions initiated by Nigeria, Ghana and Cote'de Ivoire, the three dominant economies in the sub-region are usually viewed with suspicion by other member states. This situation impacts negatively on consensus building. The implication is that resolutions are taken at the institutional level, but when it comes to implementation, they are interpreted differently to suit the whims and caprices of the leadership of individual member-states.

\section{Recommendations}

ECOWAS should revisit its Protocol on Trade Liberalization and revise it in line with the emerging realities of globalization. Globalization should not be a threat to regional integration, but should rather enhance it. One of the ways ECOWAS can take advantage of globalization is to move away from the long held position of exporters of primary commodities and importers of finished goods. To compete in the global arena, they should engage in light manufacturing and use their comparative advantage in agricultural products to deepen intra African trade. Agricultural products should be processed before being exported. In this way, the value added makes it more competitive. A country like Nigeria prides itself with being the largest producer of cassava. Instead of exporting cassava, they should be processed into industrial and pharmaceutical starch before exporting. Transportation infrastructure should also be improved upon. There should be a sub-regional railway network linking all the countries in the sub-region. This will stimulate trade and provide a gateway especially for the landlocked countries. Finally, ECOWAS leaders should develop the political will required to implement its decisions.

\section{References}

AFDB/OECD/UNDP (2017) Africa Economic Outlook.

Anugwom, E (2006) Economic globalization, poverty and social inequality in Nigeria.Nigeria Journal of International Affairs, 32, 2, 37-58.

Atakpa, O.E. (2015) Globalization and its effects on developing countries in O. Eminue\& M. Dickson (eds.) Key issues in international relations, Nsukka: University of Nigeria Press Limited.

Camara, S (2001) Francophone regionalism and its impact on West African integration.Thesis submitted to the department of international studies, florida international university in partial fulfillment of the requirements for MA degree in international studies.[online] Available: http://www.digitalcoms.fiu/edu/cgi.view content. (August 24, 2018)

Collier, P. (2007). The bottom billion.New York: Oxford University Press.

ECOWAS revised treaty (1993), Abuja: ECOWAS Commission.

Ereke, E;Okonkwo W; Okolie, R.C (2016) Globalization versus disintegration: Implication of trade liberalization for intra-regional trade in West Africa. International Affairs \& Global Strategy,46, 20-30.

Fafowora, O.O (1998). Management imperatives of globalization management in Nigeria. Journal of Nigeria Institute of Management,34(4)

Fayomi, O \&Adeola, G (2015) Ecowas and sub-regional integration in West Africa: An appraisal.Covenant University Journal of Politics and International Affairs, 3, 1, pp. 29-40.

Haas, E.B. (1958). The uniting of Europe: Political social and economic forces. Stanford, Stanford University Press.

Hartzenberg, T. (2011). Regional integration in Africa.World Trade Organization Economic Research and Statistics Division, Staff Working Paper ERSD, pp. 1-27.

Moravcsik, A. (2008). The new liberalism. In C.Reus-Smith \& D. Snidal (eds.) The oxford handbook of international relations, Oxford, New York: Oxford University Press.

Moseley, W. G.; Carney, J \& Becker, L (2010). Neoliberal policy, rural livelihoods and urban food security in West Africa: A comparison of Gambia, Cote d'Ivoire \& Mali.Proc National Academy of Science USA, 107 (13) 51749.

Official Journal of the Economic Community of West African States (ECOWAS), 1, June 1979.

Official Journal of the Economic Community of West African States (ECOWAS), 2, June, 1980. 
Official Journal of the Economic Community of West African States (ECOWAS), 6, Jan. 1985.

Official Journal of the Economic Community of West African States (ECOWAS), 14, Dec, 1988.

Okolie, A.M \& Eke, O.A. (2016) Cultural globalization and citizen diplomacy: Reflections on Nigeria's diaspora defense in South Africa.South East Journal of Political Science, 2, (1).

Olayode, K. (2006) Globalization, sustainable development and state capacity in Africa.Nigerian Journal of International Affairs, 32 (1), pp.9-27.

Sodaro, M.J. (2008) (ed.) Comparative politics ( $3^{\text {rd }}$ edition): A global introduction, New York: McGraw-Hill Higher Education.

Sylla, N.S. (2017) The cfa franc: French monetary imperialism in Africa.Review of African political economy blog. [Online]Available: http://roape.net2017/05/18cfa-franc-french-monetary-imperialism-africa. (August 24, 2018).

World Bank (1996) Global economic prospects and developing countries, Washington D.C. 